Richard Berengarten - Daša Marić

\title{
Tin Ujević (1891-1955): Twelve Poems / Translated from Croatian by Richard Berengarten and Daša Marić
}




\section{Daily Lament}

How hard it is not to be strong,

how hard it is to be alone,

and to be old, yet to be young!

and to be weak, and powerless,

alone, with no one anywhere,

dissatisfied, and desperate.

And trudge bleak highways endlessly,

and to be trampled in the mud,

with no star shining in the sky.

Without your star of destiny

to play its twinklings on your crib

with rainbows and false prophecies.

- Oh God, oh God, remember all

the glittering fair promises

with which you have afflicted me.

Oh God, oh God, remember all

the great loves, the great victories,

the wreaths of laurel and the gifts.

And know you have a son who walks

the weary valleys of the world

among sharp thorns, and rocks and stones, 
through unkindness and unconcern, with his feet bloodied under him, and with his heart an open wound.

His bones are full of weariness, his soul is ill at ease and sad, and he's neglected and alone, and sisterless, and brotherless, and fatherless, and motherless, with no one dear, and no close friend,

and he has no-one anywhere except thorn twigs to pierce his heart and fire blazing from his palms.

Lonely and utterly alone under the hemmed in vault of blue, on dark horizons of high seas.

Who can he tell his troubles to when no-one's there to hear his call, not even brother wanderers.

Oh God, you sear your burning word too hugely through this narrow throat and throttle it inside my cry.

And utterance is a burning stake, though I must yell it out, I must, or, like a kindled log, burn out. 
Just let me be a bonfire on

a hill, just one breath in the fire,

if not a scream hurled from the roofs.

Oh God, let it be over with,

this miserable wandering

under a vault as deaf as stone.

Because I crave a powerful word, because I crave an answering voice, someone to love, or holy death.

For bitter is the wormwood wreath

and deadly dark the poison cup, so burn me, blazing summer noon.

For I am sick of being weak, and sick of being all alone (seeing I could be hale and strong)

and seeing that I could be loved), but I am sick, sickest of all to be so old, yet still be young! 


\section{Frailty}

In this mist, in this rain -

oh drunken heart, don't drown in pain.

Love unrequited gave no rest,

so now you yearn for earth's breast,

And all your longing, cry of a slave,

is to find some quiet grave:

here my soul will soon expire

and here will wither my desire

on the waves of our blue, blue sea

and white, white pebbles cover me,

and my needs will all come home

under Blessed Heaven's dome,

with sun, calm blue, and clarity,

beneath the ground that once bore me. 


\section{Star on High}

He loves no less who does not waste his words,

but asks and cares too much, though seeming dumb,

and his whole scope of loving (like a crumb

of bread to feed to hungry teeth), he hoards,

preserving it to give some star on high -

his soul, his heart, his distant destiny.

His silence says: in this world's alien loneliness,

flowers and sonnets occupy my dreams,

with plant-pots perched on seasoned wooden beams our poverty's pure, simple lines of loveliness.

beneath the veil of day and night's clean blue,

I'm dreaming: I shall come, I'll come for you. 


\section{From The Necklace (1926)}

\section{I}

Come closer, darkness, lay your hand

across the horizon's wilderness

and cover all of no man's land

with secrecy and cloudiness.

Come closer, dusky haziness

till midnight thickens through the whole

wide world with dreams and drowsiness,

and while it sleeps, sing - from the soul.

V

These words - ripe harvests of black light,

these songs - ripened in silence - reach

cracked and bursting from deep night -

like beggared hands outstretched, beseech -

I'm no poet, but I do know pain -

so I must love my human hurt.

So, from my tears, l'll braid a chain

to ornament a dowry shirt.

- With pearl and coins of minted gold

worth more than any poet wrote -

if only, my beloved child,

you'll wear my necklace at your throat. 
XI

Blessed morning, you cascade

roaring lightfalls in this room.

How can pain make me afraid, dead already, in my tomb?

Well, perhaps you can ignite buried sparks from ash and dust since the lilac and the light still swell longing in your breast.

When I lift your veil, you show lines of quiet, forms of grace in shelves of books, row on row then the whole room's careworn face.

And yet, there's something still I miss from this crib without a cross, a smile upon dear lips, the kiss of flowers in a waterglass.

Blessed morning, while you dress this room in your translucent robe, I have no fear of death's caress.

Only give love back to this Job.

XIV

Amid the pressing milling throng

without a guide and fatherless.

I've lived alone and groaned too long: 
groans bear my seal of hopefulness.

I hunted every sound and sight,

I gladly parcelled out my soul,

I flexed my bow, my aim was right,

and every shot attained its goal.

I blazed to give out more to all,

with light my letter, God my trust,

and my own spirit criminal

if thorn and bramble were my crust.

But now the dreariest to end

all things is, in this dreary hell,

my spirit's dead - my oldest friend -

and I a cracked and empty bell.

XVIII

Each smile strikes a fresh flare ablaze,

each word, sharp as a gunshot, sounds

into our breasts, torn many ways,

in through our hearts' constricted grounds.

We dream green pastures, where peace shines,

hearthsmoke misting in blue breeze,

clustered grapes strung on their vines,

and deep sad summer-ripened seas.

We weep whole babbling mountain springs,

for moss of secret haunt and hollow,

and when done with such sorrowings 
yearn for cleaner tears to follow.

Our pain is endless, like the wail

of mourners at some village death, and misery, like alcohol, sears fire, fire, on my every breath.

Each smile strikes a fresh flare ablaze, each word, sharp as a gunshot, sounds into our breasts, torn many ways, in through our hearts' constricted grounds.

\section{$X X$}

Listen how in this perfumed dark our nerves' thin wires are twanged to flame as if struck by a nettle's spark.

For wounding us, they'll take the blame.

In this deep hush, with glory filled, our epic dawn sets, lost from view, yet vision from this strife is spilled through the green ranks of the avenue.

The beauty of our grieving frays, its splendid silk and velvet folds like dewy rainbows, fade in haze, fringed like the moon in blues and golds.

Listen how in this perfumed dark our nerves' thin wires are twanged to flame as if struck by a nettle's spark. 
for wounding us, they'll take the blame.

XXI

Tonight, my forehead gleams

and sweat drips in each eye;

my thoughts blaze through dreams,

tonight, of beauty I shall die.

The soul's core is passion deep

in night's abyss, a blazing cone.

Hush, weep in silence. Let us weep

and let us die. We'll die alone.

$X X V$

Who'll understand why - no one will

I rail at God each time I pray?

Within my flesh my soul lies ill.

A woman makes me waste away.

Instead of staying in my shell

when young and green I sought renown

in the wide world - but here in hell

now wear this thorn and wormwood crown.

With each tear, more tears long to blend,

consoling each sad syllable.

Aye, Hope is all: but here's an end,

my life, my world, my hope - farewell.

XXXI 
Deep in that heart, black wounds he dare not show;

he's weary, cursed, a being in distress, that sparkle in the eyes, that starry brow you're dead, Tin. All your paths are emptiness.

Death is your love, in every step you take, death, in your belly and in every breath, death is your drink and daily bread you break, in expectation and attainment, death.

What use blind love or hope without a goal, what use desire's wild dash, when there's no cure through breathing lungs or heartbeats, for the soul,

and though your loves are beautiful and pure like faded perfume in a broken bowl, none of your babbling larksong can endure?

\section{XXXII}

The Gulf! Whole oceans scaled over my head, and gold fish fashioned out of crystallites, I ask where Madam Moonlight's lain abed, and blue horizons haze blue mountain heights.

The dawn is spiked with delicate clear dread, thought's needles - piercing, lucid - snap and freeze.

No scales or spirals raise me, spirited, nor mirrorings of rocked realities.

The heart's a world unfathomed, fertile, deep, and man, beneath his lead sky, breaks and sinks, 
while life, a seagull, soars above his head.

Aye, well-fed easy woman, stuffed on bread,

thought's rhythms broke our last connecting links,

but oh, how heart and pulse beat, beat and leap.

\section{(c) (1) $(9)$}

Creative Commons Attribution-NonCommercial-NoDerivatives 4.0 International License 